\title{
Epidemiologic Study of Retinoblastoma in Recife, Pernambuco - Brazil: January 1985 - July 1997
}

\author{
Estudo Epidemiológico do Retinoblastoma no Recife - Pernambuco - Brasil: \\ janeiro 1985 - julho 1997
}

Armando Anderson Abreu ${ }^{(1,2)}$

Liana O. Ventura ${ }^{(1)}$

Sunny Silveira Abreu ${ }^{(1)}$

Lízia Regis ${ }^{(1)}$

Vera Morais ${ }^{(3)}$
Luis Mário C. Calheiros ${ }^{(4)}$

\section{SUMMARY}

Background: Retinoblastoma is by far the most frequent malignant intraocular tumor of childhood. This study was performed to characterize the clinical, diagnostic, treatment and prognostic aspects in patients with retinoblastoma in three reference centers for this pathology in the city of Recife, Pernambuco - Brazil.

Methods: A consecutive series of 85 patients with retinoblastoma was reviewed. The authors selected 66 patients $(77.6 \%)$ that fulfilled the inclusion criteria for these study.

Results: Of a total of 66 patients with retinoblastoma, $4.5 \%$ had a previous history of the disease in the family. Males were more affected than females at a ratio (male/female) of 1.12. The mean age of appearance of the first symptoms was 23.8 months, with leukocoria and ocular hyperemia being the most frequent. The mean age at time of diagnosis was 31.7 months and for surgical treatment 32.8 months. The right eye was affected in $42.4 \%$ of the cases and the left was involved in $37.9 \%$ of cases. The tumor was unilateral in $80.3 \%$ and bilateral in $19.7 \%$ of the cases. There was extraocular involvement in $62.1 \%$, and it was intraocular in $37.9 \%$ of the patients. Treatment was surgery combined with chemotherapy in $47.0 \%$ of the patients. $27.3 \%$ of the patients died and $19.7 \%$ abandoned the treatment.

Conclusions: The data on the epidemiology of retinoblastoma found in our city resembles that of other developing countries, concerning the epidemioloy of retinoblastoma.

Keywords: Retinoblastoma: clinic, diagnosis, treatment and prognosis.

\section{INTRODUCTION}

Retinoblastoma is the most frequent ocular malignant tumor in the one

Presented at the Annual Meeting of the American Association for Pediatric Ophthalmology and Strabismus, Toronto, Canadá, 1999.

(1) Department of Pediatric Ophthalmology, Fundação Altino Ventura.

(2) HOPE-Hospital de Olhos de Pernambuco, RecifePernambuco, Brazil.

(3) Department of Pediatric Oncology, Hospital Oswaldo Cruz, Recife-Pernambuco, Brazil.

(4) Hospital doCâncerdePernambuco, Recife-Pernambuco, Brazil.

Address for correspondence: HOPE - Hospital de Olhos de Pernambuco. Rua Francisco Alves, 887, Recife-Pernambuco, Brazil. CEP 50070-490. Fax: 55814214651 . Phone: 55814214344. 
pediatric tumors in $\mathrm{Mexico}^{3}$. Numbers related to the frequency of retinoblastoma in the Brazilian population are still unknown ${ }^{6}$.

Clinical manifestations of the tumor vary according to staging at recognition time, leukocoria, strabismus and low visual acuity being the most frequent $1,3,4,7$.

There are many options for treatment depending on the diameter and extension of the tumor, unilateral or bilateral involvement and systemic conditions of the patient. In the localized form, cryotherapy, photocoagulation and brachytherapy with radioisotope plaques cause few complications and cure small tumors. In disseminated and extraocular tumors these methods are not sufficient ${ }^{4}$. Enucleation is the only form of treatment presently resulting in the safe cure of the tumor, but at a very high cost with complete loss of the eye involved and significant esthetical change. Chemotherapy is the therapy of choice for extraocular dissemination of the tumor. Authors have used this method for selective cases of intraocular tumors motivated by the hope of preserving eyes with the possibility of some degree of function and to minimize the aggressive effects of radiotherapy which does not occur in Latin America where frequently tumor diagnosis is made at an advanced stage ${ }^{3-8,11}$.

There are times when a combination of therapies is necessary to achieve good results. Prognosis will depend on the degree of histological differentiation of the tumor and whether there is optic nerve involvement or choroid invasion of the tumor tissue ${ }^{4}$.

This study has the objective of determining clinical aspects, diagnosis, treatment and prognosis of retinoblastoma patients seen at three centers of reference in the city of Recife, Pernambuco-Brazil.

\section{SUBJECTS AND METHODS}

Clinical records of consecutive children with retinoblastoma diagnosis, seen at the three principal reference centers of the state: Hospital Oswaldo Cruz (HUOC), Hospital do Câncer de Pernambuco (HCP) and Fundação Altino Ventura (FAV), from January 1985 to July 1997 were reviewed. The search identified 85 retinoblastoma patients. Of these, 66 (77.6\%) were selected for this study considering the need of standardizing required data. Diagnosis was established through signs and symptoms, confirmed by the histopathological study. Clinical staging was accomplished by the ophthalmologist through indirect binocular ophthalmoscopy performed in both eyes, under scleral identation and using anesthesia in children who did not cooperate; for the anatomopathological examination the pathologist's report was used. Using these data, retinoblastoma was classified according to the protocol proposed by Reese and Ellsworth for intraocular tumors and that proposed by the Children Cancer Study Group (CCSG) for extraocular tumors. In the case of bilateral tumors the more involved eye was considered ${ }^{9}$.
Family history, gender, age at diagnosis and surgery of the first eye, laterality, staging of the tumor at diagnosis time, treatment and follow-up were recorded.

\section{RESULTS}

Sixty-six patients seen between January 1985 and July 1997 at three centers of reference for this disease were included in this study. Family history of retinoblastoma was informed in three cases $(4.5 \%)$. Of the total of patients $35(53.0 \%)$ were males and $31(47.0 \%)$ females. The male/female ratio was $1 / 12$.

Figure 1 shows the age distribution of the study patients at presentation. The age range varied from birth to 13 years, with a mean age of 23.8 months.

Main sign of retinoblastoma in this group was leukocoria followed by hyperemia and low visual acuity (Figure 2).

The patients' age at diagnosis ranged from five months to

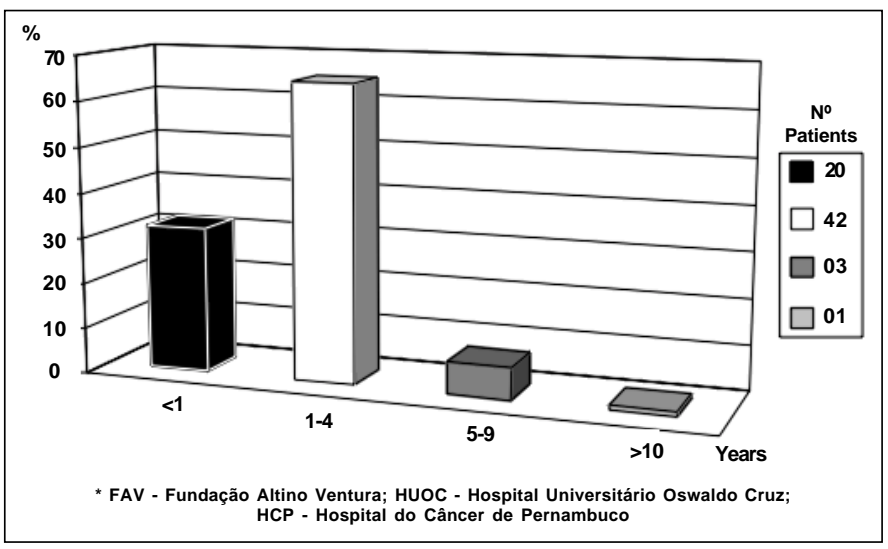

Fig. 1 - Patient distribution according to age in the years of first signs and symptoms. FAV *, HUOC *, HCP *. January 1985 - July 1997.

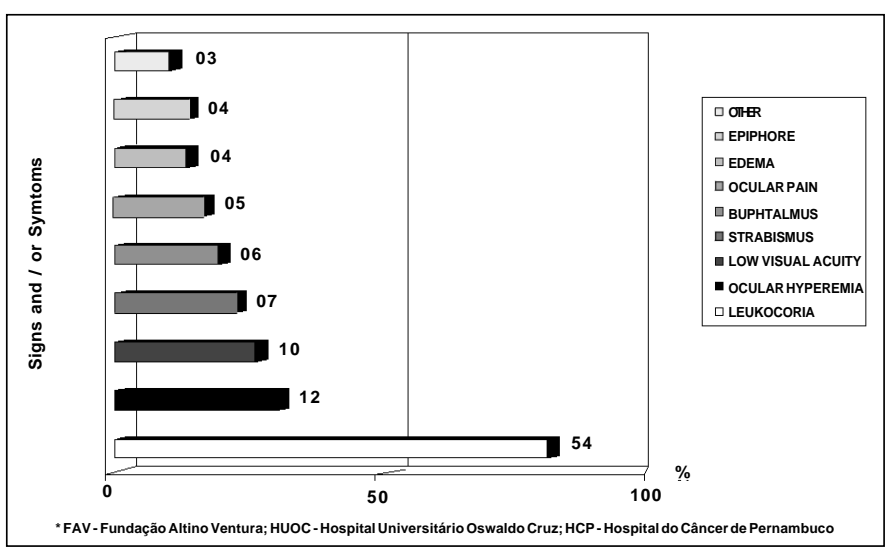

Fig. 2 - Patient distribution according to main signs and/ or symptoms FAV *, HUOC *, HCP *. January 1985 - July 1997. 


\section{ANÚNCIO}




\section{ANÚNCIO}


14 years with a mean of 31.7 months and at the time of surgical treatment ranged from five months to 14 years, with a mean of 32.8 months. Seven cases (10.6\%) were diagnosed before the first year of age, $62(93.9 \%)$ before five years of age, and the remainder above this age.

Tumor was unilateral in 53 cases $(80.3 \%)$ and bilateral in $13(19.7 \%)$. Among the unilateral tumors, the right eye was affected in 28 of the cases $(42.4 \%)$ and the left in $25(37.9 \%)$.

Intraocular involvement was detected in 25 patients $(37.9 \%)$ and extraocular in $41(62.1 \%)$. Figure 3 shows tumor staging.

Patient distribution for the treatment selected is shown in Figure 4.

The mean time of follow-up was 33.2 months with a range of 1 to 103 months. Of the total of patients 18 (27.3\%) died and $13(19.7 \%)$ abandoned the treatment.

\section{DISCUSSION}

Retinoblastoma is the most frequent intraocular tumor in childhood ${ }^{7}$. Although frequency data on the disease is unknown in Brazil, there are geographical variations accor-ding to the different regions $9,11,12$.

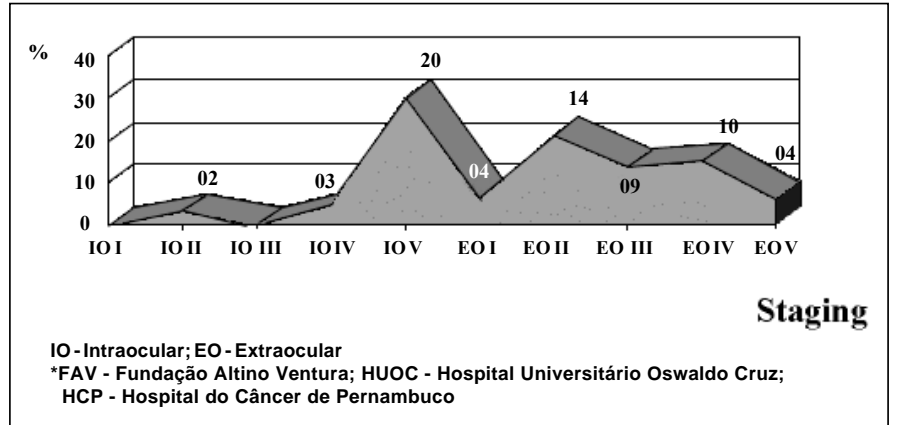

Fig. 3 - Patient distribution per tumor staging at time of diagnosis. *FAV, *HUOC, *HCP. January 1985 - July 1997.

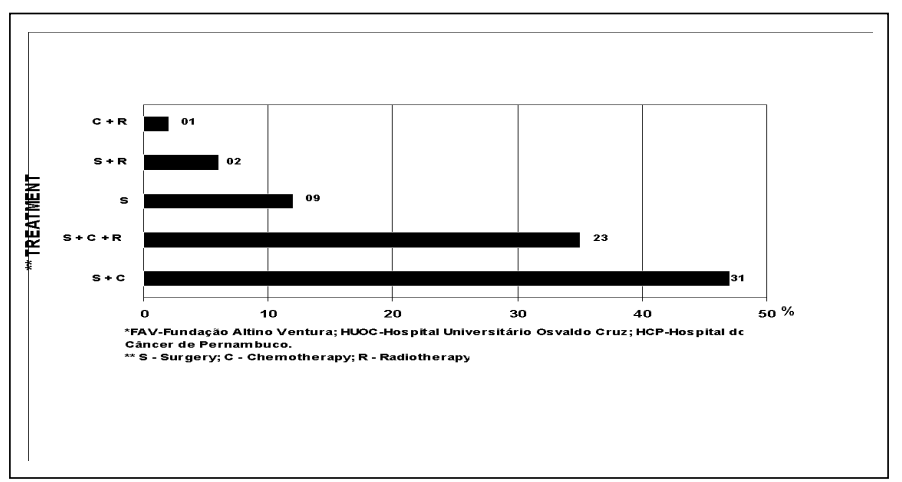

Fig. 4 - Patient distribution per treatment. FAV $^{*}$, HUOC*, HCP*. January 1985 - July 1997.
The data obtained in the present study point out specific characteristics of retinoblastoma in a pediatric population in the state of Pernambuco, analyzed at the three main services of reference, which attends almost all patients suffering from the disease.

Familial frequency of retinoblastoma of $4.5 \%$, found in three patients of this study, is compatible with that of $12.0 \%$ of previous ones ${ }^{1,9}$.

Previous reports state that there is no gender favoring of the disease, unlike others indicate a male/female ratio varying from 1.6 to $2.0^{1,2,4,7,9,10}$. In the sample studied, there which was, nevertheless a slight trend towards males, with a male/ female ratio of 1.12 .

The age at tumor signs and symptoms observed by family members varies from zero to 113 months ${ }^{12}$, which is similar to what was found in the present study (from zero to 156 months). Leukocoria was reported in $81.8 \%$ of the cases and in $30.3 \%$ this was noted before the first year of age. There are references of observation of the first signs and symptoms in approximately $44.6 \%$ of the patients before the first year of life ${ }^{12}$. In $95.0 \%$ of the patients tumor diagnosis has been made before the age of five years and, in $40.0 \%$ before the first year of life ${ }^{7}$. In this study, the frequency of retinoblastoma was reduced with age presenting a higher incidence between the first and the fourth year of age. It was diagnosed in $93.9 \%$ of the cases before the age of five years and in $10.6 \%$ of cases before the first year of life, which is in agreement with a previous study ${ }^{10}$.

Although there are reports denying trend to which eye is involved, the present analysis indicated a higher incidence of right eye involvement that has equally been noted by other authors ${ }^{1,3}$.

Tumor frequency regarding unilateral and bilateral involvement varies from $3: 1$ to $2: 1$; in this series of patients the ratio was $4: 1^{7,12}$. Bilateral cases were diagnosed earlier (20.9 months) than unilateral ones (34.5 months) which is consistent with the literature ${ }^{5}$.

In the last years higher frequency and actual survival rates of intraocular tumors have been reported, although extraocular tumors represent 36.1 of the cases ${ }^{11}$. The wide gap between sign and symptom appearance (23.8 months) and the time treatment is introduced (32.8 months) at a specialized center, probably accounts for the large amount of advanced stage tumors found in the study's patients. In $91.5 \%$ of the cases tumor staging was established as being between degree $\mathrm{V}$ intraocular (IOV) and V extraocular (EOV), and most of the tumors were extraocular $(62.1 \%)$. Specific treatment was applied on average 1.1 months after characterization of the tumor. Nevertheless the delay with which the patients arrived for treatment at specialized centers, allowed undisturbed tumor development and 18 patients (27.3\%) finally died and $94.4 \%$ of the patients were diagnosed as extraocular disease.

At the time of this study in the state of Pernambuco, ophthalmologic examination in childhood is not performed routinely and yearly as in developed countries. Reference 
Services for retinoblastoma treatment are located in the capital and due to the lack of information of health care professionals, the children examined receive only symptomatic treatment until diagnosed for retinoblastoma.

\section{CONCLUSION}

Considering the social and economic conditions of the patients with difficulties in commuting to the Capital of the state, and the lack of information regarding the value of follow-up and treatment of children, there has been a high follow-up loss in 13 of the cases (19.7\%), with the possibility of children dying in their birthplace without the Hospital being notified.

Therefore, it is important to emphasize the need of carrying out campaigns to inform the population about the early observations of signs and symptoms of retinoblastoma, and the value of a routine annual ophthalmologic examination, with special emphasis to retina mapping.

\section{AKNOWLEDGMENT}

We thank Sylvia Lemos Hinrichsen, MD, Department of Research, Fundação Altino Ventura, for her editorial assistance.

\section{RESUMO}

Objetivo: $O$ retinoblastoma é o tumor maligno intraocular mais freqüente da infância. O objetivo deste estudo foi avaliar aspectos clínicos, de diagnóstico, tratamento e prognóstico em pacientes portadores de retinoblastoma atendidos em três centros de referência para esta patologia na cidade do Recife - PE.

Métodos: Revisamos 85 prontuários de portadores de retinoblastoma e apresentamos o resultado da análise de 66 destes pacientes, atendidos durante o periodo de janeiro de 1985 a julho de 1997.

Resultados: Apenas 4,5\% tinham história pregressa da doença. O sexo masculino foi mais acometido numa razão homem/mulher de 1,12. A média de idade ao surgimento dos primeiros sintomas foi de 23,8 meses, sendo leucocoria e hiperemia ocular os mais freqüentes. A média de idade ao diagnóstico foi de 31,7 meses e a média de idade ao tratamento cirúrgico foi de 32,8 meses. O olho direito, com $42,4 \%$ dos casos, foi mais acometido que o esquerdo (37,9\%). O tumor era unilateral em $80,3 \%$ dos casos e bilateral em 19,7\%. Os tumores eram extra-oculares ao diagnóstico em $62,1 \%$, e intra-oculares em 37,9\%. O tratamento mais instituído foi a cirurgia associada à quimioterapia, em $47 \%$ dos casos. 27,3\% dos pacientes tratados foram a óbito e 19,7\% abandonaram o tratamento. Conclusões: Os dados encontrados em nosso estado assemelham-se àqueles observados em países em desenvolvimento, no que concerne à epidemiologia do retinoblastoma.

Palavras-chave: Retinoblastoma: clínica, diagnóstico, tratamento e prognóstico.

\section{REFERÊNCIAS BIBLIOGRÁFICAS}

1. Sanders BM, Draper GJ, Kingston JE. Retinoblastoma in Great Britain 196980: incidence, treatment, and survival. Br J Ophthalmol 1988;72:576-83.

2. Mahoney MC, Burnett WS, Majerovics A, Tanenbaum H. The epidemiology of ophthalmic malignancies in New York State. Ophthalmology 1990;97:1143-7.

3. Bravo-Ortiz JC, Mendoza-Sanches HF, Fajardo-Gutierrez A. Algumas características epidemiológicas del retinoblastoma en niños residentes del Distrito Federal. Bol Med Hosp Infant Mex 1996;53:234-9.

4. Shields JA, Shields CL. Intraocular tumors. Philadelphia, Saunders, 1992;p.578.

5. Rubenfeld M, Abramson DH, Ellsworth RM, Kitchin FD. Unilateral vs. bilateral retinoblastoma correlations between age at diagnosis and stage of ocular disease. Ophthalmology 1986;93:1016-9.

6. Rodrigues MLV. Oftalmologia Clínica Rio de Janeiro: Cultura Médica, 1992;760.

7. Taamboli A, Podgor MJ, Horm JW. The incidence of retinoblastoma in the United States: 1974 through 1985. Arch Ophthalmol 1990;108:128-32.

8. Greenwald M, Strauss LC. Treatment of intraocular retinoblastoma with carboplatin and etoposide chemotherapy. Ophthalmology 1996;103:1989-97.

9. Lira RPC, Leoncio MP, Pinho J, Rocha G, Lira PC. Retinoblastoma extraocular: estudo de 37 casos. Arq Bras Oftalmol 1995;58:480-5.

10. Gutierrez AF, Aranguré MM, Delgado AG, Sanchez HM, Espinosa JG, Garcia MCM. Epidemiologia de las neoplasias en niños residentes del Distrito Federal (1982 - 1991). Bol Med Hosp Infant Mex 1995;52:507-16.

11. Erwenne CM, Pacheco JCG, Antonelli CG, Saba LB. Retinoblastoma: Sobrevida atuarial. Arq Bras Oftalmol 1989;52:2426-9.

12. Rocha FJ, Erwenne CM, Saba LB, Paacheco JCG. Retinoblastoma: encaminhamento ao hospital A. C. Camargo/Fundação Antonio Prudente durante 15 anos sequenciais. Arq Bras Oftalmol 1992;55:7-13.

\section{Novidades na Internet!:!}

Agora no site CBO você tem disponível todas as informações na íntegra dos

Arquivos Brasileiros de Oitalmologia

httpe//www.cbo.com.br/abo 